Egyptian Poultry Science Journal

http://www.epsj.journals.ekb.eg/

ISSN: 1110-5623 (Print) - 2090-0570 (Online)

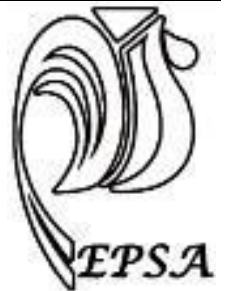

\title{
EFFECTS OF SELECTION FOR FAST GROWTH RATE ON JAPANESE QUAIL LAYING PERFORMANCE AND FITNESS TRAITS
}

\author{
B. Y. F. Mahmoud ${ }^{1}$, D. A. M. Semida ${ }^{1}$, E. A. El-Full ${ }^{1}$ and A. M. Emam ${ }^{1,2}$
}

${ }^{1}$ Poult.Prod.Dep., Fac. of Agric, Fayoum Uni., 63514 Fayoum, Egypt.

${ }^{2}$ Corresponding author: Ahmed M Emam Email: ame04@ fayoum.edu.eg

Received: 24/11/2019

Accepted: $18 / 12 / 2019$

\begin{abstract}
This work aimed to study the effects of selection for fast growth rate on some laying and fitness performance in Japanese quail using 1157 females (706 for the selected line and 451 for the control line). The most important results obtained as follows: Generation significantly affected all egg studied traits indicating that the $4^{\text {th }}$ generation $\left(\mathrm{G}_{4}\right)$ had the earliest age at first egg (AFE) and age at the first ten eggs (AGE 10 ) accompanied by the heaviest body weight at first egg $\left(\mathrm{BW}_{\mathrm{AFE}}\right)$ and desirably had lower days needed to produce the first ten eggs $\left(\mathrm{DN}_{10}\right)$ and laid heavier average egg weight

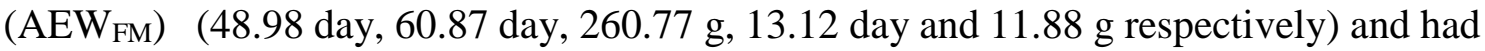
higher number of eggs $\left(\mathrm{EN}_{\mathrm{FM}}\right)$, heavier egg mass for the first month of production $\left(\mathrm{EM}_{\mathrm{FM}}\right)$, and favorably lower pause duration length (PDL $\left.\mathrm{PL}_{\mathrm{FM}}\right)$ than other generations being of $24.53 \mathrm{egg}, 291.32 \mathrm{~g}$ and 1.76 day, respectively. Moreover, the $\mathrm{G}_{4}$ had higher fertility $(88.20 \%)$ and hatchability $(85.42 \%)$ associated with preferably lower early and late embryonic mortality\% than other generations.

The selected line attained AFE at earlier age (50.63 day) with heavier BW $\mathrm{AFE}_{\text {(260.59g) }}(26)$, and lower $\mathrm{DN}_{10}$ (14.06 day) and $\mathrm{AGE}_{10}$ (64.44 day), laid more $\mathrm{EN}_{\mathrm{FM}}$ (22.63egg), higher $\mathrm{EM}_{\mathrm{FM}}(263.67 \mathrm{~g})$, earlier age after first month of production $\left(\mathrm{AGE}_{\mathrm{FM}}, 80.63\right.$ day), larger clutch size $\left(\mathrm{CS}_{\mathrm{FM}}, 5.20\right)$ and shorter PDL $\mathrm{FM}_{\mathrm{F}}$ (1.89 day) and had preferably higher fertility (80.69\%), hatchability $(74.14 \%)$ but undesirably higher early embryonic mortality\% $(2.68 \%)$ than the control line.

There were favorable negative correlations between growth rate during 1-21 days of age $\left(\mathrm{GR}_{1-21}\right.$.) And each of AFE, $\mathrm{DN}_{10}, \mathrm{AGE}_{10}, \mathrm{PDL}_{\mathrm{FM}}$ and $\mathrm{AGE}_{\mathrm{FM}}$ and had preferably positive rg's with each of $\mathrm{BW}_{\mathrm{AFE}}, \mathrm{EN}_{\mathrm{FM}}, \mathrm{EM}_{\mathrm{FM}}$, clutch number for the first month of production and $\mathrm{CS}_{\mathrm{FM}}$, it seemed these traits can be indirectly improved through the selection for fast $\mathrm{GR}_{1-21}$.
\end{abstract}

Key words: Japanese quail, fast growth rate, egg production, fertility and genetic gain. 


\section{B. Y. F. Mahmoud ${ }^{1}$ et al.}

\section{INTRODUCTION}

Either short or long term selection programs on Japanese quail have focused on body weight (BW) enhancement at fixed ages mostly at 28 or 35 days age or early egg production (Khaldari et al., 2010, Narinc and Aksoy, 2012 and Taskin et al., 2017). Unfortunately, increasing body weight has been accompanied by negative complications such as incidence of excessive fatness which is unproductive moreover, the reproductive potential of quail is adversely affected (Havenstein et al., 1994, Nicholson, 1998 and Decuypere et al., 2003).

The reduction in different reproduction traits, such as egg production, fertility, and hatchability due to selection for body weight which has a positive effect on egg weight increase (Anthony et al., 1996 and Nestor et al., 2008). There were correlations between both embryo development and hatchability with hatching egg weight (Rocha et al., 2008 and Grzegrzółka and Gruszczyńska, 2019). It is well known that genetic background of lines affected the differences of these traits (Brah et al., 2001). The relationships between chronological age, body weight and sexual maturity are complicated (Oruwari and Brody, 1988), selection for growth was very effective on increasing overall body weight at a specific age, it has altered some physiological relationships that are critical with respect to optimizing sexual development in terms of age. The selection program effects not only change growth pattern, age at first egg, reproductive and fitness traits, but also will be resulted in negative correlation between the high body weight and reproductive traits such as fertility and egg traits (Sadeghi et al., 2013). Further breeding should consider not only how to increase production but also how to alleviate correlated side effects by extending or changing selection goals for obvious economic reasons and also because of the unacceptability of some correlated responses to an increasing number of breeder. Since, there were little or no information could be found in literature on the studied $\mathrm{GR}_{1-21}$ trait and its relationships with egg and fitness performance of Japanese quail therefore, this work aimed to study the consequences of selection for fast growth rate on some laying performance and fitness traits in Japanese quail.

\section{MATERIALS AND METHODS}

This work was carried out at the farm of the Poultry Research Center, Faculty of Agriculture, Fayoum University. A selection experiment for fast growth rate during the period from one to 21 days of age according to the aggregate breeding values of the selection criterion was continued for four consecutive generations using a total number of 6998 birds including 1157 Japanese quail females (706 females for the selected line and 451 for the control line) which were recorded egg production traits for 30 days after first eggs as shown in Table 1.

The selected breeders were housed (two females were randomly assigned to each male) in breeding cages. Mating of close relatives were avoided to decrease the rate of inbreeding depression. Eggs were daily collected in a pedigree system for each family depending on the shell color and patterns of each female when ages of females were 11-14 weeks of age. According to NRC (1994), from 35 days of age to the end of the experiment, a breeder diet containing $20 \%$ crude protein, $2900 \mathrm{~K} \mathrm{Cal} \mathrm{ME}, 2.25 \%$ calcium and $0.43 \%$ available phosphorous was supplied. The light system was 16 hours of light per day through out production 
Japanese quail, fast growth rate, egg production, fertility and genetic gain.

period. Birds were kept under the same managerial hygienic and environmental conditions.

\section{Studied Traits:}

\section{Egg production-related traits:}

The studied or calculated traits were individually recorded for each female during the first month of production:

1. Age at first egg (AFE, day).

2. Body weight at first egg (BW $\left.\mathrm{AFE}_{\mathrm{AF}} \mathrm{g}\right)$.

3. Days needed to produce the first ten eggs ( $\mathrm{DN}_{10}$, day).

4. Age at the first ten eggs (AGE 10 , day).

5. Number of eggs produced in the first month of production ( $\left.\mathrm{EN}_{\mathrm{FM}}, \mathrm{egg}\right)$.

6. Egg mass for the first month $\left(\mathrm{EM}_{\mathrm{FM}}\right.$, g).

7. Average egg weight $\left(\mathrm{AEW}_{\mathrm{FM}}, \mathrm{g}\right)$ in the first month of production.

8. Clutch number for the first month

$\left(\mathrm{CN}_{\mathrm{FM}}\right.$, as a number of clutches /hen).

9. Clutch size $\left(\mathrm{CS}_{\mathrm{FM}}\right.$, as an average of clutch eggs /hen).

10. Pause duration length (PDLFM, day) in days.

11. Age after first month of production

(AGEFM, day).

Fitness traits:

Fertility $\%: \quad=$ (Number of fertile eggs/Number of total eggs set) x100.

Hatchability\%: = (Number of hatched chicks / Number of fertile eggs) x 100

Embryonic mortality traits:

After hatching, the remaining eggs were cracked to account for dead embryos at an early embryonic stage and at a late embryonic stage as a percentage of the total number of eggs set for each female (early embryonic mortality\% and late embryonic mortality\%) in all generations. Early embryonic mortality was classified as embryo died before nine days of development (before black pigmentation appearance) however, late embryonic mortality was classified as embryo died after nine days of development.

\section{Statistical analyses}

Egg production and fitness traits were analyzed by PROC MIXED (SAS, 2011) to calculate the generation and line specific means by the following model:

$Y_{i j k l}=\mu+a_{i}+G_{j}+L_{k}+g_{j} l_{k}+e_{i j k l}$

Where:

$\mathrm{Y}_{\mathrm{ijk} \mathrm{k}}$ : is the observation for a trait $\mu$ : is the overall mean, a: is the random additive genetic effect of the $i^{\text {th }}$ animal, $G$ : the effect of $j^{\text {th }}$ generation, $L$ : the effect of $k^{\text {th }}$ line,

$\mathrm{g}_{\mathrm{j}} \mathrm{l}_{\mathrm{k}}$ : : the effect of $\mathrm{j}^{\text {th }}$ generation with the $\mathrm{k}^{\text {th }}$ line and $\mathrm{e}_{\mathrm{ijk}}$ : is the random error term; the random variable was the birds within line. Means of generation were compared using multiple range test (Duncan, 1955).

\section{Genetic Parameters:}

Both univariate and bivariate linear animal models used to estimate heritabilities $\left(\mathrm{h}^{2}\right)$ of studied traits and correlations (REML procedures by WOMBAT program software, Meyer, 2007) as follows:

The univariate model to estimate

direct $\mathrm{h}^{2}$ was:

$\mathrm{Y}=\mathrm{Xb}+\mathrm{Za}+\mathrm{e}$

The bivariate model to estimate

correlations between selection criterion

trait and egg production-related traits

was:

$\left[\begin{array}{l}y_{1} \\ y_{2}\end{array}\right]=\left[\begin{array}{cc}x_{1} & 0 \\ 0 & x_{2}\end{array}\right]\left[\begin{array}{l}b_{1} \\ b_{2}\end{array}\right]+\left[\begin{array}{cc}z_{1} & 0 \\ 0 & z_{2}\end{array}\right]\left[\begin{array}{l}a_{1} \\ a_{2}\end{array}\right]+$

$\left[\begin{array}{l}e_{1} \\ e_{2}\end{array}\right]$

Where: for trait $\mathrm{i}(\mathrm{i}=1,2), \mathrm{y}_{\mathrm{i}}=$ vector of observations, $b_{i}=$ vector of fixed effects (i.e., generation and line, $\mathrm{a}_{\mathrm{i}}=$ vector of random direct genetic effects, $\mathrm{e}_{\mathrm{i}}=$ vector of random residual effects, and $\mathrm{X}_{\mathrm{i}}$ and $\mathrm{Z}_{\mathrm{i}}$ are incidence matrices relating the observations to the respective fixed and direct genetic effects.

\section{Genetic gain:}

Genetic gain evaluation depending on breeding values for the egg production- 


\section{B. Y. F. Mahmoud ${ }^{1}$ et al.}

related traits through a mixed model method (Henderson, 1973), by determining the difference between the averages of the breeding values of the first and the last generation within each line, separately.

\section{RESULTS AND DISCUSSION}

Performance of egg production-related traits:

\section{Generation effect on egg production-} related traits:

Selection generation significantly affected all egg production- related traits studied indicating that the $4^{\text {th }}$ generation of selection had the earliest $\mathrm{AFE}$ and $\mathrm{AGE}_{10}$ (47.98 and 60.87 days) whereas the latest estimates for AFE (54.66 days) was obtained by the $3^{\text {rd }}$ generation whereas other generations were attained $\mathrm{AGE}_{10}$ at later ages ranging from 66.29 to 67.78 days (Table 2). Elkomy et al. (2019) reported lower AFE ranging from 39.34 to 48.45 days compared with this study.

Significant differences among generations for AFE were reported by Farrag (2011), Okenyi et al. (2013), Emam (2015), Meabed (2015) and Mahmoud et al. (2014 and 2016). In the contrary, Naser and Abbas (2012) reported insignificant generation effect on AFE. Quail in the $4^{\text {th }}$ generation of selection showed the heaviest $\mathrm{BW}_{\mathrm{AFE}}(260.77 \mathrm{~g})$ and desirably had lower $\mathrm{DN}_{10}$ (13.12 days) and laid heavier AEW (11.88g) whereas the $2^{\text {nd }}$ generation had lighter AWE of $11.34 \mathrm{~g}$ than other generations. Elkomy et al. (2019) reported that heavier egg weights $(13.26: 14.52, \mathrm{~g})$ than those of this study.

Both Okenyi et al. (2013) and Mahmoud et al. (2014) reported significant differences among generations for $\mathrm{BW}_{\mathrm{AFE}}$. There were significant generation fluctuations in $\mathrm{DN}_{10}$ as reported by Mahmoud et al. (2014) and Emam (2015). In the contrary, Meabed (2015) found that there was insignificant difference due to generation for $\mathrm{DN}_{10}$.

Line effect on egg production-related traits:

The selected line attained AFE at earlier age with heavier $\mathrm{BW}_{\mathrm{AFE}}$ and lower $\mathrm{DN}_{10}$ and $\mathrm{AGE}_{10}$ than the control line whereas, the control line had insignificantly heavier $\mathrm{AEW}_{\mathrm{FM}}$ than selected line (Table 2). Similarly, line had significant effect on AFE as reported by Farrag (2011), Narendra Nath et al. (2011), Sadeghi et al. (2013), Mahmoud et al. (2014), Emam (2015), Meabed (2015) and Farahat et al. (2018). However, Karabağ et al. (2010) and Alkan et al. (2013) reported insignificant line effect on AFE. Abou Khadiga et al.(2016) found significant superiority of the selected line for AFE (3.03) and $\mathrm{BW}_{\mathrm{AFE}}(+10.38)$. Emam (2015) reported that selection for high $\mathrm{BW}_{21}$ resulted in desirable decrease in $\mathrm{DN}_{10}$ of 11.71 days for the selected line fed $24 \%$ CP diet quails vs. 13.28 days for the control fed $24 \%$ CP diet quails. There were significant differences among lines for $\mathrm{DN}_{10}$ favoring the selected line for selection index (AFE, $\mathrm{BW}_{\mathrm{AFE}}$ and $\mathrm{DN}_{10}$ ) and trends of selection changes were towards early maturity and shorter $\mathrm{DN}_{10}$ (Mahmoud et al., 2014 , Abou Khadiga et al., 2016 and Farahat et al., 2018). Regardless of generation number, averages for AEW were higher in selected lines for high body weight than those in the control lines (Karabağ et al., 2010, Farrag, 2011 and Narendra Nath et al., 2011).

\section{Generation effect on egg production traits:}

All egg production traits studied significantly affected by both selection generation and line effects (Table 3). The $4^{\text {th }}$ generation had higher $\mathrm{EN}_{\mathrm{FM}}$, heavier $\mathrm{EM}_{\mathrm{FM}}$, earlier $\mathrm{AGE}_{10}$ and lower PDLFM 
Japanese quail, fast growth rate, egg production, fertility and genetic gain.

(24.53egg, 291.32g, 77.98 and 1.76 days, respectively) than other generations however, the $2^{\text {nd }}$ generation had more $\mathrm{CN}_{\mathrm{FM}}$ with shorter $\mathrm{CS}_{\mathrm{FM}}$ as compared to other generations $(6.07$ clutch and 3.68egg) and the tallest PDLFM was shown for the $1^{\text {st }}$ generation. Similarly, generation significantly affected EN and EM (Naser and Abbas, 2012 and Emam, 2015). Estimated EN from the results of Elkomy et al. (2019) were ranged from 19.83 to 23.93 eggs per month and agreed with this study.

There were fluctuations across generations in EM's during different periods up to 70 days of egg production due to significant generation effects reported by Mahmoud et al. (2014 and 2016). On the other hand, Meabed (2015) reported that generation insignificantly affected $\mathrm{EM}_{\mathrm{FM}}$.

\section{Line effect on egg production traits:}

Quails of the selected line laid more $\mathrm{EN}_{\mathrm{FM}}$ eggs, higher $\mathrm{EM}_{\mathrm{FM}}$, earlier $\mathrm{AGE}_{\mathrm{FM}}$ (+9.43\%, +8.46\%, -5.38days), larger $\mathrm{CS}_{\mathrm{FM}}$ and shorter PDLFM $(+25.60 \%$ and $11.68 \%)$ than those of the control line (Table 3). Similarly, line had significant effects on EN as reported by many investigators (Narendra Nath et al., 2011, Alkan et al., 2013 , Okenyi et al., 2013 and Meabed, 2015) favoring the selected lines than their controls. Conversely, Farrag (2011) found that the females of selected line for high $\mathrm{BW}_{4}$ produced lower EN and EM than the control females during 90 days of lay. While, Alkan et al. (2013), Meabed (2015) and Mahmoud et al. (2016) found significant line effect on EM favoring the selected lines over generations than the control line. Selection for high BW at different ages resulted in significant undesirable increase in clutch number and pause duration length $\left(\mathrm{CN}_{\mathrm{FM}}\right.$ and PDL $_{F M}$ ) comparing to control line (Karabağ et al. , 2010, Alkan et al., 2013 and Sadeghi et al., 2013). In other words, selection criteria clearly influenced EN, EM, CN and PDL.

\section{Performance of fitness traits:}

Generation effect on fitness traits:

As shown in Table 4 , the $4^{\text {th }}$ generation had higher fertility\% and hatchability\% associated with preferably lower early and late embryonic mortality\% than other generations however, the $3^{\text {rd }}$ and the $1^{\text {st }}$ generations had the highest early and late embryonic mortality\%, $(4.74 \%$ and $2.01 \%$, respectively) than other generations. Similar trend of significant generation effect on fertility $\%$ was reported by Abdel Fattah (2006) and Okenyi et al. (2013). However, Farrag (2011) reported insignificant differences due to generations and lines for fertility\% and hatchability\% from fertile egg. Similarly, Okenyi et al. (2013) found insignificant differences due to generations for hatchability from fertile egg\%.

\section{Line effect on fitness traits:}

Quails of the selected line had preferably higher fertility\%, hatchability\% $(+5.64 \%$ and $+4.89 \%$ ) but undesirably higher early embryonic mortality\% (+18.06\%) than those of the control line. These results are in agreement with the findings of Abdel Fattah (2006) who found that selected lines for higher $\mathrm{BW}_{42}$ and $\mathrm{GR}_{1-42}$ had higher fertility\% and hatchability from fertile egg than control line. Whereas, Farrag (2011) and Sadeghi et al.(2013) reported lower fertility\% and hatchability from fertile egg for that selected lines than the control line. As well as there were significant differences due to line effect on fertility\% and hatchability from fertile egg reported by Farahat et al. (2018).

Karagecili and Karadaş (2017) reported that intensive selection applied on commercial poultry caused high metabolic rate of embryos and their nutritional requirements have also increased, 


\section{B. Y. F. Mahmoud ${ }^{1}$ et al.}

deficiency to meet these requirements nutrition has negative effects on some traits such as embryonic development, fertility and hatchability .

\section{Heritability, genetic and phenotypic correlations between GR1-21and egg production traits:}

Each of $\mathrm{AGE}_{10}, \mathrm{BW}_{\mathrm{AFE}}$ and $\mathrm{AFE}$ had higher $h^{2}$ of $0.25, \quad 0.24$ and 0.20 , respectively than other egg productionrelated and egg production traits ranged from 0.07 to 0.19 as shown in Table 5 . Similarly, several authors reported moderate $h^{2}$ ranged from 0.21 to 0.37 for AFE (Özsoy and Aktan, 2011 and Abou Khadiga et al., 2016).On the other hand, Hidalgo et al. (2011) reported higher $\mathrm{h}^{2}$ estimates for AFE ranged from 0.53 to 0.75 than $h^{2}$ estimates in this study. Heritability estimates for $\mathrm{BW}_{\mathrm{AFE}}$ and $\mathrm{AGE}_{10}$ of this study were in agreement with the reports of other studies $\mathrm{BW}_{\mathrm{AFE}}$ (Abou Khadiga et al., 2016) being 0.25 and $\mathrm{AGE}_{10}$ (Mahmoud et al., 2016) was 0.28. Conversely, Özsoy and Aktan (2011) and Okenyi et al. (2013) reported high $\mathrm{h}^{2}$ estimates for $\mathrm{BW}_{\mathrm{AFE}}$ being 0.58 and 0.46 , respectively. This wide range of $\mathrm{h}^{2}$ estimates could be due to the differences in populations, method of estimation and statistical models.

The GR $_{1-21}$ had preferably negative correlations either genetically or phenotypically with each of AFE, $\mathrm{DN}_{10}$, $\mathrm{AGE}_{10}, \mathrm{PDL}_{\mathrm{FM}}$ and $\mathrm{AGE}_{\mathrm{FM}}$ (rg:-0.30, $0.14,-0.09,-0.004$ and -0.03 vs rp: $-0.12,-$ $0.03,-0.07, \quad-0.013$ and -0.01 , respectively). On the other hand, $\mathrm{GR}_{1-21}$ was genetically and positively correlated in a favorable trend with each of $\mathrm{BW}_{\mathrm{AFE}}$, $\mathrm{EN}_{\mathrm{FM}}, \mathrm{EM}_{\mathrm{FM}}$ and $\mathrm{CS}_{\mathrm{FM}}$ (rg: 0.26, 0.36, 0.10 and 0.19 ). Also, positive phenotypic correlations were found between $\mathrm{GR}_{1-21}$ and each of with each of $\mathrm{BW}_{\mathrm{AFE}}, \mathrm{EN}_{\mathrm{FM}}$, $\mathrm{EM}_{\mathrm{FM}}$, and $\mathrm{CS}_{\mathrm{FM}}$ ranged from 0.02 to 0.29 .
There was negative rp between $\mathrm{GR}_{1-21}$ and $\mathrm{CN}_{\mathrm{FM}}$ being -0.19 (Table 5). No previous information could be found on the studied $\mathrm{GR}_{1-21}$ trait and their relationship with egg production performance of Japanese quail. Positive rgs estimates between $\mathrm{BW}_{21}$ with AFE, DN $10, E N$ and EM were positive and ranged from 0.09 to 0.32 , from 1.14 to $1.22,0.16$ to 0.84 and 0.16 to 0.24 , respectively as well as, rp estimates were $0.20,-0.14,0.24$ and 0.24 , respectively (Emam, 2015). Genetic correlations can arise in several ways as illustrated by Falconer (1989), they can be caused by pleiotropic gene effect, linkage, pleiotropic occurs when one locus affects multiple traits.

Genetic gain estimates were favorable but insignificant for most egg production traits (AFE, $\mathrm{DN}_{10}, \mathrm{EN}_{\mathrm{FM}}, \mathrm{EM}_{\mathrm{FM}}, \mathrm{AGE}_{10}$ and AGE $_{\mathrm{FM}}$ ) being - 1.22, $-0.58,+3.07,+13.24$, -2.39 and -2.22 , respectively. Hence selection based on $\mathrm{GR}_{1-21}$ could improve these traits may be due to the genetic correlations between $\mathrm{GR}_{1-21}$ and previous traits .Therefore, decreased AFE could increase the number of eggs during the laying period. However, this led to a decrease in egg weight due to the negative genetic and phenotypic correlations between egg weight and egg number .In the current study estimates of genetic gain were undesirably and insignificant effects on $\mathrm{BW}_{\mathrm{AFE}}, \mathrm{AEW}_{\mathrm{FM}}, \mathrm{PDL}_{\mathrm{FM}}, \mathrm{CN}_{\mathrm{FM}}$ and $\mathrm{CS}_{\mathrm{FM}}(-0.67,-0.51,+0.37,-0.16$ and -0.09 , respectively).

In conclusion, selection for high $\mathrm{GR}_{1-21}$ resulted in favorable negative correlations either genetically or phenotypically with each of $\mathrm{AFE}, \mathrm{DN}_{10}$, $\mathrm{AGE}_{10}, \mathrm{PDL}_{\mathrm{FM}}$ and $\mathrm{AGE}_{\mathrm{FM}}$ and had preferably positive rg' $\mathrm{s}$ with each of $\mathrm{BW}_{\mathrm{AFE}}, \mathrm{EN}_{\mathrm{FM}}, \mathrm{EM}_{\mathrm{FM}}, \mathrm{CN}_{\mathrm{FM}}$ and $\mathrm{CS}_{\mathrm{FM}}$. It seemed these previously mentioned productive traits can be indirectly 


\section{Japanese quail, fast growth rate, egg production, fertility and genetic gain.}

improved through the selection for fast $\mathrm{GR}_{1-21}$. Some estimates of genetic gain were opposite to genetic correlations in direction which may be due to fluctuations in response to selection affecting the means of breeding values, which could be due to the population size.

\section{CONCLUSION}

Selection for fast growth rate during the period from 1 to 21 days of age in Japanese quail improved egg production traits which were represented in earlier AFE, $\mathrm{DN}_{10} \mathrm{AGE}_{10}$ and AGE $\mathrm{Am}$. Also, the selected line had higher $\mathrm{BW}_{\mathrm{AFE}}, \mathrm{EN}_{\mathrm{FM}}$, $\mathrm{EM}_{\mathrm{FM}}, \mathrm{CS}_{\mathrm{FM}}$, and lower $\mathrm{CN}_{\mathrm{FM}}$ and PDLFM compared with the control line. There were similar trends of improving fertility and hatchability resulted from selection for fast earlier growth rate. Selection for $\mathrm{GR}_{1-21}$ had desired genetic gain with most studied egg production traits (AFE, $\mathrm{DN}_{10}$, $\mathrm{AGE}_{10}, \mathrm{AGE}_{\mathrm{FM}}, \mathrm{EN}_{\mathrm{FM}}, \mathrm{EM}_{\mathrm{FM}}$ and $\mathrm{CN}_{\mathrm{FM}}$ ). The $\mathrm{GR}_{1-21}$ had positive $\mathrm{rg}$ and $\mathrm{rp}$ with $\mathrm{BW}_{\mathrm{AFE}}, \mathrm{EN}_{\mathrm{FM}}, \mathrm{EM}_{\mathrm{FM}}$ and $\mathrm{CS}_{\mathrm{FM}}$ traits, in contrary, it had negative $\mathrm{rg}$ and $\mathrm{rp}$ with AFE, $\mathrm{DN}_{10}, \mathrm{AGE}_{10}, \mathrm{PDL}_{\mathrm{FM}}$ and $\mathrm{AGE}_{\mathrm{FM}}$, therefore indirect selection could be used to enhance these traits. 
B. Y. F. Mahmoud ${ }^{1}$ et al.

Table (1): Female numbers used over four generations of the selection experiment.

\begin{tabular}{|l|c|c|c|}
\hline Generation & Line & Dams & Total \\
\hline \multirow{2}{*}{ First } & $\begin{array}{c}\text { Control line } \\
\text { Selected line }\end{array}$ & $\begin{array}{c}139 \\
178\end{array}$ & 317 \\
\hline Second & $\begin{array}{c}\text { Control line } \\
\text { Selected line }\end{array}$ & $\begin{array}{c}96 \\
172\end{array}$ & 268 \\
\hline \multirow{2}{*}{ Third } & $\begin{array}{c}\text { Control line } \\
\text { Selected line }\end{array}$ & $\begin{array}{c}80 \\
180\end{array}$ & 260 \\
\hline Fourth & $\begin{array}{c}\text { Control line } \\
\text { Selected line }\end{array}$ & $\begin{array}{c}136 \\
176\end{array}$ & 312 \\
\hline Total & \multicolumn{2}{|l}{1157} \\
\hline
\end{tabular}

Table (2): Least square means \pm SE for egg production- related traits as affected by generation and line effect.

\begin{tabular}{|c|c|c|c|c|c|}
\hline Item & AFE, day & BW $_{\mathrm{AFE}}, \mathbf{g}$ & $\mathrm{DN}_{10}$, day & AGE10, day & AEWFM, $_{\text {F }}$ \\
\hline \multicolumn{6}{|c|}{ Generation effect: } \\
\hline First & $52.97 \pm 0.53^{\mathrm{b}}$ & $255.40 \pm 1.77^{b}$ & $15.43 \pm 0.31^{\mathrm{a}}$ & $67.78 \pm 0.62^{\mathrm{a}}$ & $11.81 \pm 0.08^{\mathrm{a}}$ \\
\hline Second & $51.59 \pm 0.65^{b}$ & $261.47 \pm 2.16^{\mathrm{a}}$ & $14.95 \pm 0.35^{\mathrm{a}}$ & $66.29 \pm 0.71^{\mathrm{a}}$ & $11.34 \pm 0.08^{b}$ \\
\hline Third & $54.66 \pm 0.69^{a}$ & $259.79 \pm 2.27^{\mathrm{ab}}$ & $13.18 \pm 0.38^{b}$ & $67.16 \pm 0.77^{\mathrm{a}}$ & $11.42 \pm 0.09^{b}$ \\
\hline Fourth & $47.98 \pm 0.63^{\mathrm{c}}$ & $260.77 \pm 2.07^{\mathrm{a}}$ & $13.12 \pm 0.34^{\mathrm{b}}$ & $60.87 \pm 0.70^{b}$ & $11.88 \pm 0.08^{\mathrm{a}}$ \\
\hline \multicolumn{6}{|l|}{ Line effect: } \\
\hline Control line & $55.21 \pm 0.56^{\mathrm{a}}$ & $253.01 \pm 1.85^{\mathrm{b}}$ & $14.97 \pm 0.31^{\mathrm{a}}$ & $69.10 \pm 0.62^{\mathrm{a}}$ & $11.73 \pm 0.07$ \\
\hline Selected line & $50.63 \pm 0.28^{\mathrm{b}}$ & $260.59 \pm 0.94^{\mathrm{a}}$ & $14.06 \pm 0.16^{\mathrm{b}}$ & $64.44 \pm 0.32^{\mathrm{b}}$ & $11.60 \pm 0.04$ \\
\hline \multicolumn{6}{|l|}{$p$-value } \\
\hline Generation & 0.0001 & 0.0304 & 0.0001 & 0.0001 & 0.0001 \\
\hline Line & 0.0071 & 0.0001 & 0.0077 & 0.0001 & 0.0958 \\
\hline Generation*Line & 0.0001 & 0.4697 & 0.0708 & 0.0126 & 0.0001 \\
\hline
\end{tabular}

Means having different superscripts within each effect in the same column are significantly differed at specified probability, SE: stander error, AFE: age at first egg, BW $\mathrm{BFE}_{\mathrm{AFE}}$ body weight at first egg, $\mathrm{DN}_{10}$ : days needed to produce the first ten eggs, $\mathrm{AGE}_{10}$ : age at the first ten eggs, $\mathrm{AEW}_{\mathrm{FM}}$ : average egg weight in the first month of production, and P: Probability. 
Japanese quail, fast growth rate, egg production, fertility and genetic gain.

Table (3):Least square means \pm SE for egg production traits during the first month of Laying as affected by generation and line effect.

\begin{tabular}{|c|c|c|c|c|c|c|}
\hline Item & $\mathrm{EN}_{\mathrm{FM}}, \mathrm{egg}$ & $\mathrm{EM}_{\mathrm{FM}}, \mathrm{g}$ & $\begin{array}{l}\text { AGE }_{F M}, \\
\text { day }\end{array}$ & $\mathrm{CN}_{\mathrm{FM}}$ & $\mathrm{CS}_{\mathrm{FM}}$, day & $\begin{array}{l}\text { PDL } \\
\text { day, }\end{array}$ \\
\hline \multicolumn{7}{|c|}{ Generation effect: } \\
\hline First & $20.21 \pm 0.34^{\mathrm{b}}$ & $240.84 \pm 4.52^{\mathrm{c}}$ & $82.97 \pm 0.53^{\mathrm{b}}$ & $5.59 \pm 0.11^{\mathrm{b}}$ & $4.00 \pm 0.19^{c}$ & $2.32 \pm 0.07^{\mathrm{a}}$ \\
\hline Second & $20.31 \pm 0.36^{\mathrm{b}}$ & $231.16 \pm 4.85^{\mathrm{c}}$ & $81.59 \pm 0.65^{\mathrm{b}}$ & $6.07 \pm 0.12^{\mathrm{a}}$ & $3.68 \pm 0.20^{\mathrm{c}}$ & $2.13 \pm 0.13^{\mathrm{a}}$ \\
\hline Third & $24.34 \pm 0.40^{\mathrm{a}}$ & $278.38 \pm 5.32^{\mathrm{b}}$ & $84.67 \pm 0.69^{\mathrm{a}}$ & $4.22 \pm 0.13^{\mathrm{c}}$ & $6.64 \pm 0.22^{\mathrm{a}}$ & $1.85 \pm 0.13^{b}$ \\
\hline Fourth & $24.53 \pm 0.35^{\mathrm{a}}$ & $291.32 \pm 4.75^{\mathrm{a}}$ & $77.98 \pm 0.63^{\mathrm{c}}$ & $4.42 \pm 0.12^{\mathrm{c}}$ & $6.06 \pm 0.19^{\mathrm{b}}$ & $1.76 \pm 0.12^{b}$ \\
\hline \multicolumn{7}{|l|}{ Line effect: } \\
\hline Control line & $20.68 \pm 0.32^{\mathrm{b}}$ & $243.11 \pm 4.34^{b}$ & $85.21 \pm 0.56^{\mathrm{a}}$ & $5.50 \pm 0.06^{\mathrm{a}}$ & $4.14 \pm 0.18^{b}$ & $2.14 \pm 0.10^{\mathrm{a}}$ \\
\hline Selected line & $22.63 \pm 0.16^{\mathrm{a}}$ & $263.67 \pm 2.21^{\mathrm{a}}$ & $80.63 \pm 0.28^{b}$ & $5.04 \pm 0.11^{\mathrm{b}}$ & $5.20 \pm 0.09^{\mathrm{a}}$ & $1.89 \pm 0.05^{b}$ \\
\hline \multicolumn{7}{|l|}{$p$-value } \\
\hline Generation & 0.0001 & 0.0001 & 0.0001 & 0.0001 & 0.0001 & 0.0001 \\
\hline Line & 0.0001 & 0.0001 & 0.0001 & 0.0001 & 0.0001 & 0.0296 \\
\hline Generation*Line & 0.2792 & 0.0002 & 0.0011 & 0.0002 & 0.0011 & 0.0173 \\
\hline
\end{tabular}

Means having different superscripts within each effect in the same column are significantly differed at specified probability, SE: stander error, $\mathrm{EN}_{\mathrm{FM}}$ : number of eggs produced in the first month of production, $\mathrm{EM}_{\mathrm{FM}}$ : egg mass for the first month, $\mathrm{CN}_{\mathrm{FM}}$ : clutch number for the first month, $\mathrm{CS}_{\mathrm{FM}}$ : clutch size, PDLFM: pause duration length, $\mathrm{AGE}_{\mathrm{FM}}$ : age after first month of production and P: Probability.

Table (4): Least square means \pm SE for fitness traits during the first month of Laying as affected by generation and line effect

\begin{tabular}{|l|c|c|c|c|}
\hline Item & Fertility \% & Hatchability \% & $\begin{array}{c}\text { Early embryonic } \\
\text { mortality \% }\end{array}$ & $\begin{array}{c}\text { Late embryonic } \\
\text { mortality\% }\end{array}$ \\
\hline Generation effect: \\
\hline First & $69.50 \pm 1.32^{\mathrm{d}}$ & $65.40 \pm 1.55^{\mathrm{c}}$ & $1.79 \pm 0.14^{\mathrm{b}}$ & $2.01 \pm 0.08^{\mathrm{a}}$ \\
Second & $80.66 \pm 1.33^{\mathrm{c}}$ & $79.25 \pm 1.54^{\mathrm{b}}$ & $1.42 \pm 0.15^{\mathrm{c}}$ & $1.40 \pm 0.10^{\mathrm{b}}$ \\
Third & $85.56 \pm 1.65^{\mathrm{b}}$ & $54.48 \pm 1.90^{\mathrm{d}}$ & $4.74 \pm 0.13^{\mathrm{a}}$ & $1.44 \pm 0.12^{\mathrm{b}}$ \\
Fourth & $88.20 \pm 1.62^{\mathrm{a}}$ & $85.42 \pm 1.86^{\mathrm{a}}$ & $1.23 \pm 0.16^{\mathrm{c}}$ & $1.28 \pm 0.10^{\mathrm{b}}$ \\
\hline Line effect: & $76.38 \pm 0.13^{\mathrm{b}}$ & $70.68 \pm 1.46^{\mathrm{b}}$ & $2.27 \pm 0.12^{\mathrm{b}}$ & $1.68 \pm 0.08$ \\
\hline Control line & $80.69 \pm 0.07^{\mathrm{a}}$ & $74.14 \pm 0.92^{\mathrm{a}}$ & $2.68 \pm 0.08^{\mathrm{a}}$ & $1.54 \pm 0.05$ \\
Selected line & p-value & 0.0001 & 0.0001 & 0.0001 \\
\hline Generation & 0.0001 & 0.0385 & 0.0039 & 0.1451 \\
Line & 0.0029 & 0.5416 & 0.3175 & 0.7427 \\
Generation*Line & 0.7730 &
\end{tabular}

Means having different superscripts within each effect in the same column are significantly differed at specified probability, SE: stander error and P: Probability. 


\section{B. Y. F. Mahmoud ${ }^{1}$ et al.}

Table (5): Heritability, genetic gain, genetic and phenotypic correlations \pm SE between $\mathrm{GR}_{1-21}$ and egg production traits.

\begin{tabular}{|l|c|c|c|c|}
\hline Correlated trait & $\mathbf{h}^{\mathbf{2}} \pm \mathbf{S E}$ & $\mathbf{r g} \pm \mathbf{S E}$ & $\mathbf{r p} \pm$ SE & Genetic gain \pm SE \\
\hline $\mathrm{AFE}$ & $0.20 \pm 0.007$ & $-0.30 \pm 0.09$ & $-0.12 \pm 0.04$ & $-1.22 \pm 0.1^{\mathrm{ns}}$ \\
$\mathrm{BW}_{\mathrm{AFE}}$ & $0.24 \pm 0.001$ & $0.26 \pm 0.09$ & $0.02 \pm 0.03$ & $-0.67 \pm 0.05^{\mathrm{ns}}$ \\
$\mathrm{DN}_{10}$ & $0.07 \pm 0.030$ & $-0.14 \pm 0.06$ & $-0.03 \pm 0.03$ & $-0.58 \pm 0.02^{\mathrm{ns}}$ \\
$\mathrm{EN}_{\mathrm{FM}}$ & $0.17 \pm 0.008$ & $0.36 \pm 0.05$ & $0.29 \pm 0.05$ & $3.07 \pm 0.20^{\mathrm{ns}}$ \\
$\mathrm{EM}_{\mathrm{FM}}$ & $0.19 \pm 0.007$ & $0.10 \pm 0.09$ & $0.12 \pm 0.03$ & $13.24 \pm 134^{\mathrm{ns}}$ \\
$\mathrm{AEW}_{\mathrm{FM}}$ & $0.17 \pm 0.008$ & $-0.09 \pm 0.03$ & $0.08 \pm 0.03$ & $-0.51 \pm 0.09^{\mathrm{ns}}$ \\
$\mathrm{PDL}_{\mathrm{FM}}$ & $0.07 \pm 0.006$ & $-0.004 \pm 0.004$ & $-0.013 \pm 0.003$ & $0.37 \pm 0.05^{\mathrm{ns}}$ \\
$\mathrm{CN}_{\mathrm{FM}}$ & $0.09 \pm 0.004$ & $0.04 \pm 0.004$ & $-0.19 \pm 0.040$ & $-0.16 \pm 0.01^{\mathrm{ns}}$ \\
$\mathrm{CS}_{\mathrm{FM}}$ & $0.17 \pm 0.003$ & $0.19 \pm 0.02$ & $0.02 \pm 0.004$ & $-0.09 \pm 0.001^{\mathrm{ns}}$ \\
$\mathrm{AGE}_{10}$ & $0.25 \pm 0.006$ & $-0.09 \pm 0.02$ & $-0.07 \pm 0.04$ & $-2.39 \pm .09^{\mathrm{ns}}$ \\
$\mathrm{AGE}_{\mathrm{FM}}$ & $0.17 \pm 0.008$ & $-0.03 \pm 0.007$ & $-0.01 \pm 0.008$ & $-2.22 \pm 0.30^{\mathrm{ns}}$ \\
\hline
\end{tabular}

$\mathrm{h}^{2}$ : heritability, rg: genetic correlation, rp: phenotypic correlation, SE: stander error, AFE: age at first egg, $\mathrm{BW}_{\mathrm{AFE}}$ : body weight at first egg, $\mathrm{DN}_{10}$ : days needed to produce the first ten eggs, $\mathrm{AGE}_{10}$ : age at the first ten eggs, $A E W_{\mathrm{FM}}$ : average egg weight in the first month of production, $\mathrm{EN}_{\mathrm{FM}}$ : number of eggs produced in the first month of production, $\mathrm{EM}_{\mathrm{FM}}$ : egg mass for the first month, $\mathrm{CN}$ : clutch number for the first month, $\mathrm{CS}$ : clutch size, PDL: pause duration length, $\mathrm{AGE}_{\mathrm{FM}}$ : age after first month of production and ns: non-significant.

\section{REFERENCES}

Abdel Fattah, M. H. 2006. Selection for increased body weight and growth rate in Japanese quail. Ph. D. Thesis, Fac. Agric., Fayoum Univ., Egypt.

Abou Khadiga' G., Mahmoud, B. Y. F. And El-Full, E. A. 2016. Genetic evaluation of early egg production and maturation traits using two different approaches in Japanese quail. Poult. Sci. 95 :774-779.

Alkan, S. , Karsli, T., Karabag, K. And Gali, C. A. 2013. The effects of selection and season on clutch traits and egg production in Japanese quails
(Coturnix coturnix Japonica) of different lines. Süleyman Demirel Üniversitesi Ziraat Fakültesi Dergisi 8: 71-77.

Anthony, N.B., Nestor K.E. and Marks H. L. 1996. Short-term selection for four-week body weight in Japanese quail. Poult. Sci., 75: 1192-1197.

Brah, G. S., Chaudhary, M. L. And Sandhu, J. S. 2001 Direct and correlated responses to selection for 4week body weight in two lines of Japanese quails. Arch Tierzucht, 44: 99-108.

Decuypere, E., Bruggeman, V., Barbato, G. F. And Buyse, J. 2003. 
Japanese quail, fast growth rate, egg production, fertility and genetic gain.

Growth and reproduction problems associated with selection for increased broiler meat production. Pp: 13-28. In: Poultry Genetics, Breeding and Biotechnology, edited by Muir. W. M. And Aggrey, S. E, CABI Publishing, London.

Duncan, D. B. 1955. Multiple range and multiple F-tests. Biometrics, 11: 1-42.

Elkomy, H. E., Taha, A. E., Basha, H. A., Abo-Samaha, M. I., and Sharaf. M. M. 2019. Growth and reproduction performance of Japanese quails (Coturnix coturnix japonica) under various environments of light colors. Slov. Vet. Res., 56 119-127.

Emam, A. M. 2015. Selection for high body weight under two nutritional environments in Japanese quail.. Ph. D. Thesis, Fac. Agric., Fay. Univ., Egypt.

Falconer, D. S., 1989. Introduction to Quantitative Genetics. $3^{\text {rd }}$ ed, Longman Group, Essex, England.

Farahat, G. S. , Mahmoud, B. Y., ElKomy, E. M. And El-Full, E. A. 2018. Alterations in plasma constituents, growth and egg production traits due to selection in three genotypes of Japanese quail. J. Agric. Sci. 156: 118-126.

Farrag, S. A. A. 2011. Genetic variation within and between quail lines selected for high body weight at four weeks of age and egg production using DNA fingerprinting. Ph. D. Thesis, Kazakh National Agrarian University, Faculty of Farm Technology and Food Safety, Kazakhstan.

Grzegrzółka, B. And Gruszczyńska, J. 2019. Correlations between egg weight, early embryonic development, and some hatching characteristics of Japanese quail (Coturnix japonica). Turk J Vet Anim Sci 43: 253-258.

Havenstein, G., Ferket, P. R., Scheideler, S. E. And Larson, B. T.
1994. Growth, livability and feed conversion of 1957 vs 1991 broilers when fed" typical" 1957 and 1991 broiler diets. Poult. Sci., 73: 17851794.

Henderson, C. R. 1973. Sire evaluation and genetic trends. J. Anim. Sci. 1973, Issue Symposium. 10-41.

Hidalgo, A. M. , Martins, E. N., Dos Santos, A. L. , Oliveira de Quadros, T. C. , Ton, A. P. S. And Teixeira, R. 2011. Genetic characterization of egg weight, egg production and age at first egg in quails. Revista Brasileira de Zootecniav 40: 95-99.

Karabag, K. , Alkan, S. And Balcloglu, M. S. 2010. The differences in some production and clutch traits in divergently selected Japanese Quails. Kafkas Universitesi Veteriner Fakultesi Dergisi 16: 383-387.

Karagecili, M.R. and Karadaş, F. 2017. The Importance of Maternal and/or In ovo Antioxidant Feeding for Gene Expression and Performance in Poultry. J. Agric. Sci., 27, 276-284.

Khaldari, M., Pakdel, A., Yegane, H. M. , Javaremi, A. N. And Berg, P. 2010. Response to selection and genetic parameters of body and carcass weights in Japanese quail selected for 4-week body weight. Poult. Sci. 89 :18341841.

Mahmoud, B. Y. F., Abou Khadiga, G. And El-Full, E. A. 2014. Direct and correlated responses to short-term index selection for some economic traits of Japanese quail. Egypt. Poult. Sci. 34:761-778.

Mahmoud, B. Y. F., Abou Khadiga, G., and El-Full, E. A. 2016. Correlated response to selection for some egg performance traits in egg line of Japanese quail. Anim. Prod. Sci. 56: 913-917 
Meabed, S. A. A. 2015. Response to three generation of divergent selection for shank length in Japanese quail. Ph. D. Thesis, Fac. Agric., Fay. Univ., Egypt.

Meyer, K. 2007. WOMBAT: a tool for mixed model analyses in quantitative genetics by restricted maximum likelihood (REML). J. Zhejiang Univ. Sci. B. 8: 815-821.

N R C, 1994. Nutrient Requirements of Domestic Animals. Nutrient Requirements of Poultry, $9^{\text {th }}$ Rev. Ed. Washington, DC: National Academy Press

Narendra Nath, D., Sheriff, F. R., Prabakaran, R. And Asha Rajini, R. 2011. Response to short term index selection for economic traits in meat type Japanese quail. J. Indian Vet. Sci. 9: 10-14.

Narinc, D. And Aksoy, T. 2012. Effects of mass selection based on phenotype and early feed restriction on the performance and carcass characteristics in Japanese quails. Kafkas univ vet Fark Derg 18,3: 425-430.

Naser, M. A. And Abbas, A. A. 2012. Genetic evaluation and estimation of genetic and phenotypic parameters of productive traits in quails. Iraqi. J. Poult. Sci. 6:22-38.

Nestor K. E, Anderson, J.W., Patterson, R.A. and Vellman, S. G. 2008. Genetics of growth and reproduction in the turkey. 17. Changes in genetic parameters over forty generations of selection for increased sixteen-week body weight. Poult. Sci., 87: 19711979.

Nicholson, D. 1998. The broiler industry's partner into the new millennium. World's Poult. Sci. J. 3: 271-278.
Okenyi, N., Ndofor-Foleng, H. M., Ogbu, C. C. And Agu, C. I. 2013. Genetic parameters and consequences of selection for short-term egg production traits in Japanese quail in a tropical environment. African J. Biotechnology 12: 1357-1362.

Oruwari, B. M., and Brody, T. 1988. Roles of age, body weight, and composition in the initiation of sexual maturation of Japanese quail (Coturnix coturnix japonica). Br. Poult. Sci. 29:481-488.

Özsoy, A. N. And Aktan, S. 2011. Estimation of genetic parameters for body weight and egg weight traits in Japanese quails. Trends in Anim. And Vet. Sci. 2:17-20.

Rocha, J. S. R. , Lara, L. J. C. , Baiao, N. C., Cancado, S. V., Baiao, L. E. C. And Silva, T. R. 2008. Effect of egg classification prior to setting on hatchability, embryonic mortality and chick and yolk sac weights. Arq Bras Med Vet Zootec 2008; 60: 979-986 (in Portuguese with an English abstract).

Sadeghi, R. , Pakde, A. , Shahrbabak , M. M. And Shahrbabak, H. M. 2013. Divergent selection effect on reproductive trait in Japanese quail. Research J.Poult.Sci.6:18-22.

SAS Institute Inc 2011. SAS/STAT® 9.3 User's Guide. Cary, NC: SAS Institute Inc.

Taskin A. , Karadavut, U. , Tunca, R. I., Genc, S. And Cayan, H. 2017. Effect of selection for body weight in Japanese quails (Coturnix coturnix Japonica) on some production traits. Indian J. Anim. Res. 51:358-364. 


\section{Japanese quail, fast growth rate, egg production, fertility and genetic gain.}

تأثير الاتتخاب لمعل النمو السريع على الأداء الاتتاجى العربى للسمان اليابانى البياض وصفات الموائمة

بثينه يوسف فؤاد محمود 1، دعاء عبد الحميد محمود صميده 1، إنصاف أحمد القل1 و أحمد محمد إمام1

$$
1 \text { ق بسم انتاج الدواجن - كلية الزر اعة - جامعة الفيوم }
$$

يهدف العمل الحالى الى دراسة أثر الاتتخاب لمعدل النمو السريع على صفات انتاج البيض وصفات المو ائمة للسمان

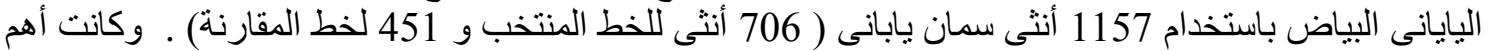

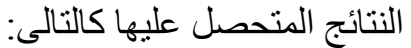

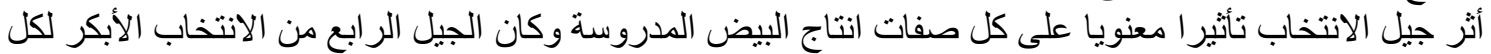

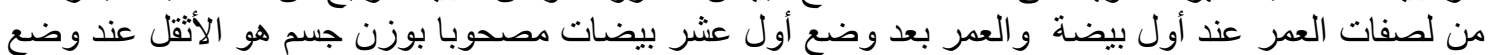

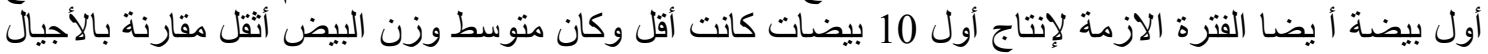

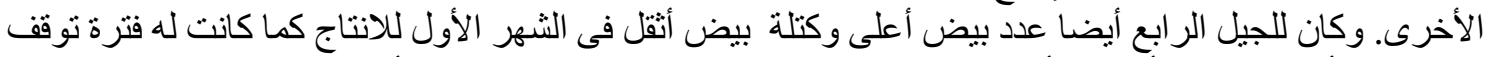

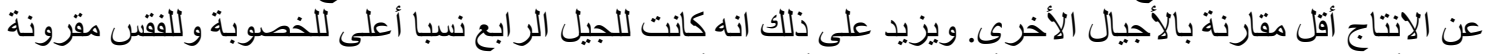

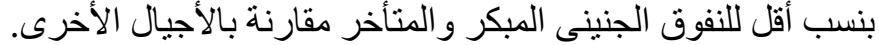

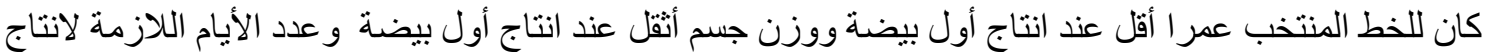

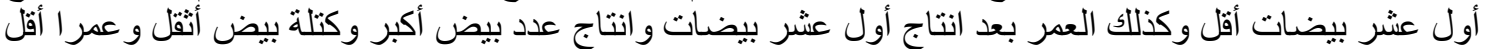

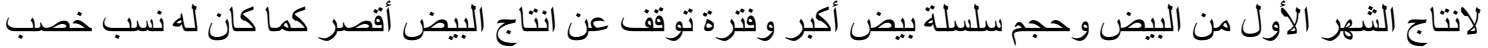

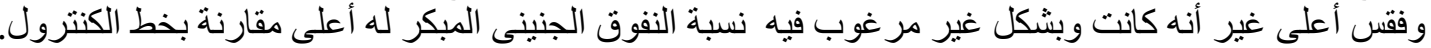

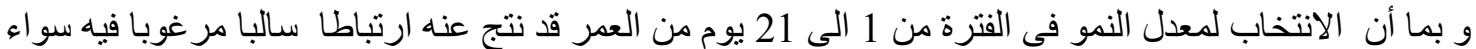

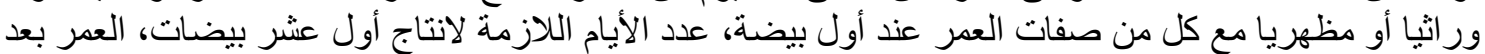

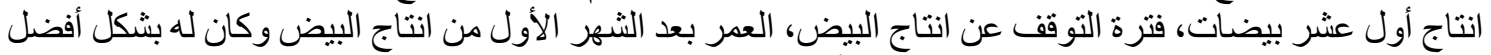

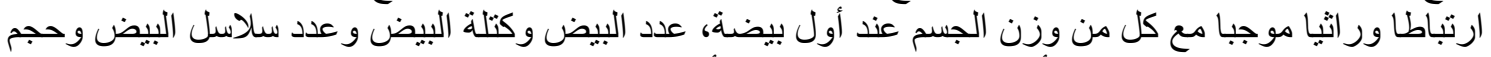

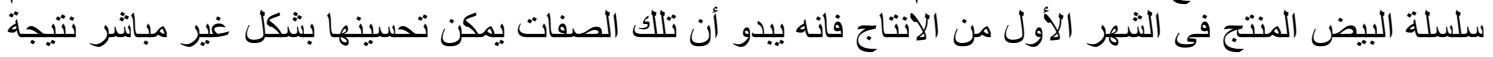

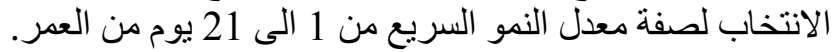

